\title{
The Evaluation of Clinical Pathway Implementation on Cerebral Infarction in the Inpatient Care Unit of Bantul X Hospital
}

\author{
Duane Ayu Fitri*, Sri Sundari**

\begin{tabular}{l}
\hline I N D E X I N G \\
\hline Keywords: \\
Implementation; \\
Clinical Pathway; \\
Cerebral Infarction;
\end{tabular}

* Correspondent Author: duaneayufitri@yahoo.co.id

* Master of Hospital Management, Universitas Muhammadiyah Yogyakarta Indonesia

** Faculty of Medicine and Health Sciences in Muhammadiyah Universitas Muhammadiyah Yogyakarta, Indonesia

Kata Kunci:

Implementasi;

Clinical Pathway;

Infark Cerebri;

\begin{abstract}
A B S T R A C T
Stroke remains one of the major health problems, not only in Indonesia but also in the world. The improvement of stroke service process is expected to support better outcomes of stroke service quality. One of the clinical management uses is the implementation of clinical pathway (CP). The purpose of this study was to explore the implementation of clinical pathway cerebral infarction in the inpatient unit of Bantul X hospital. A convergent parallel mix-method design with case study approach. The quantitative sample is the patient's total cerebral infarction medical record (June 2016November 2016, $\mathrm{n}=27$ ) and ICPAT checklist. Qualitative samples are doctors, nurses and people involved in the implementation of $\mathrm{CP}$ cerebral infarction obtained from deep interview with purposive sampling technique. The result of this study, ICPAT dimensio 1 (CP format) content and quality are good. Dimension 2 (CP documentation) moderate content and good quality. Dimension 3 (CP development) moderate content and good quality. Dimension 4 (CP implementation) content and quality are poor. Dimension 5 (CP maintenance) content and quality are moderate. Dimension 6 (role of organization) content and quality are good. Compliance rate of completeness of $\mathrm{CP}$ form is $22 \%$ and compliance of filling clinical pathway is $0 \%$. Most contraints due to busyness of the officer and time constraints. To improve the cerebral infarction CP implementation need more socialization, training, regular evaluation and full time facilitator.
\end{abstract}

Stroke masih menjadi salah satu masalah utama kesehatan, bukan hanya di Indonesia namun dunia. Dengan adanya perbaikan proses pelayanan stroke diharapkan dapat menunjang outcome kualitas pelayanan stroke yang lebih baik, yaitu dengan pemberlakuan clinical pathway (CP). Tujuan penelitian ini adalah untuk mengeksplore implementasi CP infark cerebri pad unit rawat inap rumah sakit X Bantul. Penelitian mix-method secara convergent parallel dengan pendekatan studi kasus. Sampel kuantitatif adalah rekam medis pasien infark cerebri secara total sampling (Juni 2016November 2016, =27) dan checklist ICPAT. Sampel kualitatif adalah dokter, perawat, dan orang0orang yang terlibat implementasi CP infark cerebri diperoleh dari deep interview dengan teknik purposive sampling. Hasil penelitian ini adalah ICPAT dimensi 1 (Format CP) konten dan mutu baik. Dimensi 2 (Dokumentasi CP) konten moderate dan mutu baik. Dimensi 3 (Pengembangan CP) konten moderate dan mutu baik. Dimensi 4 (Penerapan CP) konten dan mutu kurang. Dimensi 5 (Pemeliharaan CP) konten dan mutu moderate. Dimensi 6 (Peran Organisasi) konten dan mutu baik. Tingkat kepatuhan formulir CP sebesar 22\% dan kepatuhan pengisian CP sebesar 0\%. Untuk memperbaiki kepatuhan implementasi CP infark cerebri membutuhkan sosialisasi, pelatihan dan evaluasi rutin serta fasilitator waktu penuh.

(C) 2018 JMMR. All rights reserved

$\overline{\text { Article History: Received } 5 \text { F }}$ b 2017; Revised 15 Sept 2017; Accepted 25 Okt 2017

\section{INTRODUCTION}

The hospital is obliged to provide safe, quality, antidiscrimination and effective services by prioritizing the interests of patients in accordance with hospital service standards. The most important goal in health care is to produce outcomes that benefit patients, providers, and society. Achieving the desired outcome depends on the- quality of health services or hospitals. ${ }^{1}$

According to the Law of the Republic of Indonesia No. 40 of 2004 concerning the National Social Security System in Chapter 24 Paragraph 3 stipulates that the National Security Management Agency develops a health service system, a service quality control system, and a payment system for health services to improve efficiency and the effectiveness of health insurance. 
Various regulations on health services in Indonesia have set standards on the implementation of a quality control system for health insurance services, namely input, process and output. The input standards, among others, have been regulated in health facility licensing standards, starting from building standards, human resources, equipment and so on. Standard output especially related to performance at the patient level and also at the level of health service facilities, for this standard Hospital has been regulated in Hospital minimum service standards. Process standards can be divided into clinical care management processes. The management process, among others, is regulated in accreditation standards (Hospitals, Laboratories, Puskesmas), excellent service standards and so on. For clinical processes (clinical care) regulated in medical service guidelines and standards of nursing care or generally referred to as clinical guidelines that are generally published by professional organizations. One form of clinical guidelines is the clinical pathway that has the potential to be used as a tool to guarantee and improve the quality of the clinical care process. ${ }^{2}$

In Indonesia the implementation of clinical pathways related to the application of INA-DRG which is a version of the Indonesian Ministry of Health is expected to improve the efficiency and quality of health services in hospitals. INA-DRG is a case system based financing system. ${ }^{2}$ Based on a study conducted by Tiara Kusumaningtias in 2013 in "The impact of the implementation of clinical pathways on the quality of Stroke services in Bethesda Hospital Yogyakarta" obtained results that clinical pathways significantly improve stroke service processes, especially in swallowing essences, rehabilitation essays, and education when patients return.

Stroke remains one of the major health problems, not only in Indonesia but also in the world. ${ }^{3}$ It is known that stroke is the highest cause of death in Indonesia. ${ }^{4}$ The process of the service becomes one of the determinants of outcome so that there is a need for more organized stroke services to narrow the process variation. ${ }^{5}$ The improvement of stroke service process is expected to support better outcomes of stroke service quality. One of the clinical management used is the implementation of clinical pathway. ${ }^{6}$

Bantul X Hospital is one of the hospitals that has implemented clinical pathway since 2014. Determination of clinical pathway cases based on high volume and high risk cases that found in Bantul $\mathrm{X}$ hospital, one of them is cerebral infarction. Based on data in Bantul X hospital in
2015 there were 40 cases of cerebral infarction. In 2016 increased by 54 cases.

Clinical pathway is an integrated service planning concept that summarizes every step given to patients based on evidence-based medical service and nursing care standards with measurable results and within a certain period of time while in hospital. Clinical pathways are collaborative guidelines for treating patients who focus on diagnosis, clinical problems and stages of service. ${ }^{7}$

Clinical pathway is a pre-treatment concept that is compiled based on standard procedures of each profession that refers to the service standards of their respective professions, adjusted to the strata of hospital service facilities. ${ }^{8}$

Various definitions and settings of health services in various countries have caused a variety of content, structure and design. In general, clinical pathways are required to have the minimum standard format as follows.

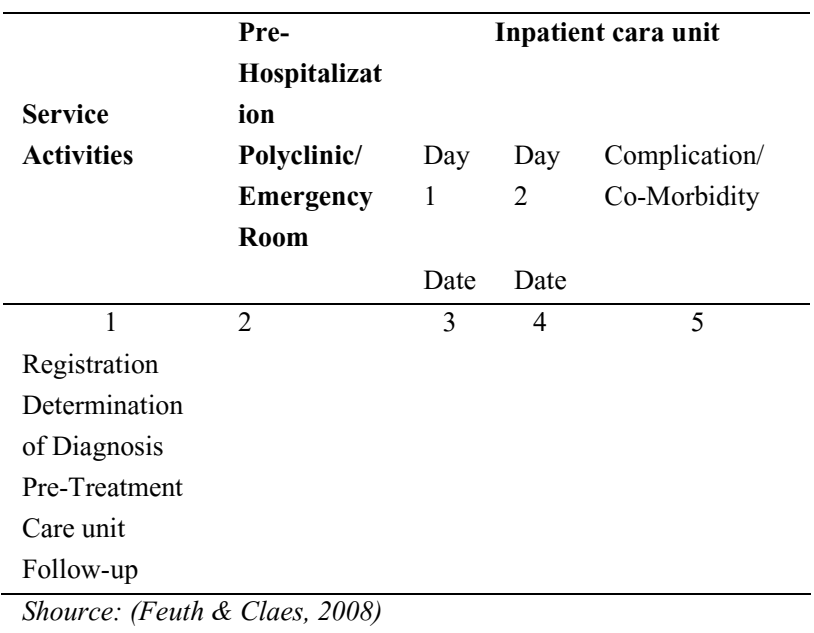

The principle in the preparation of clinical pathways, fulfills some fundamental things ${ }^{7}$, such as:

1) All service activities provided must be integrated and oriented towards patients and be continuous.

2) Involve all professions involved in hospital services for patients.

3) Within the time limit that has been determined according to the condition of the patient's illness and recorded in the form of a daily period for cases of hospitalization or hours for emergency cases.

4) Record all service activities provided to patients in an integrated and continuous manner into medical record documents.

5) Every deviation of steps in the implementation of 
clinical pathways is recorded as a variance and an analytical review is carried out in the form of an audit.

6) The variance can be due to the condition of the disease, comorbidities or complications or medical errors.

7) The variance is used as a parameter in order to maintain and improve the quality of service.

For a strategic approach, in a study in the UK carried out by the VFM Unit (NHS Wales) Project on the Clinical Resource Utilization Group between September 1995 to March 1997 on 700 people consisting of clinical staff, managers, and operational staff, obtained data on key elements that must be built in order to achieve the success of the clinical pathway. A key result of the project was the identification of five distinct and sequential stages used by organization with evidence of successful programmes of ICP activity. These stages were defined as: ${ }^{9} 1$ ) Increased awareness and commitment 2) Develop a system for implementing the Clinical Pathway 3) Documentation (and designation) 4) Implementation (trial, implementation and development) 5) Evaluation.

The first step is the most critical step. This is difficult given the density / high workload of clinical staff, cultural factors, and willingness to change. In this case, there is a need for a facilitator / coordinator who has a full-time task to ensure that clinical pathways can be applied in hospitals, especially in the awareness session phase. The Clinical Pathway is a leader driven tool, so that it will actually run if it is supported by good leadership, especially from the head of the hospital. ${ }^{9}$

There are at least 5 main things that lead to the failure of implementing clinical pathways, namely ${ }^{9}$

1) Professional culture

2) Lack of organizational support

3) Design of the Clinical Pathway

4) Inadequate time and resources

5) Ad-hoc approach

Feuth and Claes (2008) suggest that there are 4 main components of clinical pathways, which include: time frame, category of care, outcome criteria and recording variants. The time frame describes the stages based on treatment days or based on service stages such as: preoperative, intra-operative and post-operative phases. The care category contains activities that describe the care of all health teams given to patients. Activities are grouped according to the type of action at a certain time period. The results criteria contain the results expected from the standard of care provided, including long-term criteria that describe the outcome criteria of the overall care and shortterm, which describes the outcome criteria at each stage of service at a certain time period. The variant sheet records and analyzes the deviations from the standards established in the clinical pathway. The condition of a patient who is not in accordance with the standard of care or standard that cannot be done is recorded in the variant sheet.

There are two instruments that are often used to audit the contents and quality of clinical pathways. The two instruments are The ICP Key Element Checklist and The Integrated Care Pathway Appraisal Tool (ICPAT): ${ }^{10}$

1) The ICP Key Elements Checklist

Developed by Croucher (UK) in 2004 as part of a master's study on the quality of ICP used in UK national health services (UKNHS). This instrument is made based on literature in the UK and has not been validated. The purpose of this study is to identify key elements in ICP, and evaluate available ICP. A tool in the form of "The ICP key element checklist" is made based on a literature review. Each ICP must have these 14 key elements, if the ICP is out of the 14 elements listed, the format is said to be not ICP, but more likely to be a checklist or guidelines only. ${ }^{7}$

2) The Integrated Care Pathway Appraisal Tool (ICPAT)

Developed since 1999 by Whittle et al in the United Kingdom by gaining support from the West Midlands Regional Levy Board quality development association. This instrument is based on the same design as the AGREE (Appraisal of Guidelines Research and Evaluation) instrument. ICPAT is an instrument that has been validated and can be used to evaluate the content and quality of ICP, which consists of 6 dimensions. ${ }^{5}$

\section{RESEARCH METHOD}

This is a convergent parallel mix method research with case study approach on the implementation of clinical pathway in cerebral infarction case at inpatient care unit of Bantul X hospital. The quantitative data were taken in the form of simple description of documentation and clinical pathway filling in medical record and ICPAT. The qualitative data were obtained by deep interview and observation to know the implementation of clinical pathway. This research was conducted in Bantul X Hospital for two months, from November 2016 - December 2016. Samples and sampling in this research were taken by using medical records which were selected in total sampling which were all medical records of patients who suffered from cerebral infarction from June 2016 until November 2016. Samples and sampling in this research were taken by using qualitative methods selected by purposive sampling 
consisting of nurses who served on wards, wardroom heads, doctors from the emergency department, clinical pathway team leaders and hospital quality team leaders.

The inclusion criteria used in the quantitative method is the latest Clinical Pathway used in Bantul X Hospital and the medical records of patients with cerebral infarction cases from June 2016 until November 2016. At the moment, the clinical pathway had been implemented in Bantul X Hospital. The exclusion criteria used in the quantitative methods are the missing medical records/ missing data, damaged medical records which were not possible to read and use.

Respondent's characteristic for the qualitative data is the informant that has been determined by researcher in using clinical pathway of cerebral infraction and who agreed to become the informant, informant that directly related to making and implementing clinical pathway, the doctors in charge of the emergency department, the nurses who served in the inpatient care unit that ran the clinical pathway. The informants were still in duty at Bantul X Hospital.

The variables of this research are clinical pathway implementation consisting of several indicators, namely input variables (clinical pathway format, organization role, facilities and infrastructure, and human resources), process variables (documentation, development, implementation and maintenance clinical pathway), and output (clinical pathway adherence).

Quantitative analysis was done by descriptive analysis of ICPAT checklist and the data were processed by using a computer program. The qualitative data were analyzed by qualitative analysis technique with some steps which were processing and preparing data, reading whole data, analyzing more in detail by coding data, and applying coding process. Then, the result was presented or described in a narrative or qualitative report.

\section{RESULT}

\section{a. Hospital Profile}

Bantul X Hospital is a type C general hospital with 104 beds. Until 2011, the number of employees in Bantul X Hospital has reached 413 employees, including permanent employees of 273 employees and non-permanent employees of 140 employees. They are medical and nonmedical employees (Profile of Bantul X Hospital).

b. The Ward
Ward $\mathrm{A}$ is the ward of internal medicine which consists of $1^{\text {st }}$ Class and $2^{\text {nd }}$ Class wards. There is a total of 20 beds in this ward. Ward B is also the ward of internal medicine which has VIP Class and $3^{\text {rd }}$ Class. There are 31 beds there.

\section{c. ICPAT evaluation result}

(Whittle, 2009) explained the classification of ICPAT evaluation. If the result obtained from the assessment is $<50 \%$ then it is included in the criteria of poor. If it is between $50 \%$ and $75 \%$, it is indicated as in the moderate criteria. Then, if the result of the assessment is $>75 \%$, it is included in the good criteria. From the graph above, it is found that the ICPAT dimension 1 (CP format) and dimension 6 (role of organization) show the good content and quality. Dimension 2 (documentation) shows the moderate content and good quality. Dimension 3 (development) shows moderate content and good quality. Dimension 4 (implementation) shows the poor content and quality. Dimension 5 (maintenance) shows the moderate content and quality.

\section{d. Input}

Bantul X Hospital has 1 neurologist. For nursing, ward A has 15 nurses. Ward B as many as 27 nursing staffs. In order to support the smoothness of work, The B ward is equipped with nursing medical equipment. Based on the data obtained, most of the required equipment is available according to the standards specified in the ward, although there are some tools that are still lacking in number and also damaged.

Based on dimension 1 (What form is assessed by Clinical Pathway?), the content part reached $80 \%$, the quality part reached $100 \%$. The content parts that had not been evaluated were whether the clinical pathway has a final end and whether the documentation of clinical pathway can specifically record the services needed by the patients. These results were obtained from the direct observation on the clinical pathway sheets.

1) Outline of services

In this dimension shows the answer presentation yes for the content section which is $80 \%$ and the answer is for the quality part which is $100 \%$ which belongs to the good category. In the part of the content that has not been implemented is whether the clinical pathway can help decision making and whether clinical pathway documentation can record specifically the services needed by the patient. This is known from the results of direct observations on the clinical pathway sheet. 
2) The role of the profession

The role of the profession in the implementation of clinical pathway infarction cerebri is not seen by anyone who contributes to the service. This was supported by the statement of respondent 3 that,

"From the doctor's line, I never fill in, most of them fill nurses, labs don't fill up, nutrition is filled in but filling in the status and not filling in $C P$, the pharmacy is on education status, only he doesn't fill in CP."

Based on the statement, the existing clinical pathway sheet has not clearly shown the division of the professional role in carrying out and filling out the sheet.

3) Design

Clinical pathway cerebral infarction can help show a focus of attention on other factors such as comorbit, risk factors or other problems. This is supported by the statement of respondent 5 , stated

"We did put in the history in very detail, not just history but also about the risk factors, for example acute appendicitis for acute appendicitis will be looked for at any risk factors, menstrual history or anything else"

The above statement is further strengthened by the statement given by respondent 2 , stated

"... can help but be finalized when the evaluation is not done while walking"

In the quality section, dimension 1 reaches $100 \%$, which means that in both cases, the path path is used as part / unit in the service / therapy and clinical pathway describes who contributes to the service. This is supported by the statement of the respondent 5 , that

"... there are doctors, nurses, pharmacists, physiotherapists, then nutrition, specialists"

On dimension 6 which is the evaluation on the role of organization through the ICPAT sheets, the result is that the percentages of content and quality parts reached $100 \%$. On the content part, one point that got the 'yes' answer was whether in the planning at the hospital level, it includes the specific plan to develop the clinical pathway. The answer is supported by the statement of the $5^{\text {th }}$ respondent who said,

"... the special seminar will be planned next year, at the end of 2017." e. Process

In the assessment of the ICPAT sheet, the percentage of answers was obtained in the content section of $52 \%$ and the quality section was $75 \%$. In the part of content that has not fulfilled is an explanation of the situation in which the patient cannot use the clinical pathway, a mechanism to identify that the patient is included in the clinical pathway, the page number in each page, the total number of pages on each page, the date of the document review plan, the abbreviation described in the document, space to write the name of the patient in each page, a warning about the importance of completing variations, as well as a variation recording system that includes data on dates and hours, patient access to clinical pathways and conditions in which patients fill in some parts of the clinical pathway. This is based on the results of observations on the clinical pathway infarction cerebral sheet. In the part of quality that has not been fulfilled, it is about the participation of patients in the clinical pathway. This is supported by a statement by respondent 2 stating that

"No, it is internal to the hospital if the patient has the right to know the medical risks technically, if to see a different treatment again"

Based on this statement it was found that patients did not have access to their clinical pathways.

In the assessment of the ICPAT sheet for clinical pathway development items, the percentage of answers was obtained in the content section of $54 \%$ and the quality section was $82 \%$. The content section is included in the moderate category. Based on the assessment on ICPAT that has not fulfilled the existence of patient representatives who participated in reviewing clinical pathways to ensure patient confidentiality. In the quality section that has not fulfilled, namely the involvement of all staff and patients in the development process, the opinions of patients are collected during the trial and the results of the trial are discussed with the patient. This is supported by the statement of respondent 3 , that

"Supposedly all nurses, all doctors, lab staff, then there is a midwife, there is nutrition, there is a pharmacy that should fill. But it's not filled yet, so we are the nurse in the team, the CP team." 
Based on the statement that not all executive representatives participated in the process of developing clinical pathways.

For clinical pathway implementation items, the percentage of answers is $40 \%$ and the quality section is $0 \%$. Both in the content and quality section are included in the less category. In the part of content that has not fulfilled that is evidence that the hospital in the development process has examined the possible risks that can occur due to the use of clinical pathway before use, the clinical pathway use training program for staff, as well as the allocation of resources to carry out clinical pathway training. In the quality section that has not fulfilled the risk assessment by the hospital. This is supported by the statement of respondent 5 that,

"... we'll make a special seminar, it will be planned next year, end of 2017"

Based on the statement, it was stated that there was no training program for the use of clinical pathways for staff.

In the standard operating procedure for filling in the clinical pathway of Bantul X Hospital, filling in the clinical pathway starts from the Emergency Room or outpatient services. After filling out the clinical pathway and after the patient was discharged from the hospital, verification was done by the clinical pathway team and affixed with a "verified" stamp and the signing of the signature as proof of verification was carried out. Respondent 3 stated that,

"Sometimes it is not included but later if we evaluate we take it in 3 months we take the status with the diagnosis and there is no $C P$, we still enter the $C P$ so we still enter the evaluation"

Based on the statement stated that if the service from the Emergency Room or outpatient service forgot to enter the clinical pathway, the clinical pathway team that evaluated would fill the clinical pathway based on the actions taken by doctors, nutritionists, nurses, laboratory staff, and physiotherapy.

In the assessment of clinical pathway maintenance items based on ICPAT sheets, the percentage of answers is yes in the content section of $50 \%$ and the quality section is $69 \%$. In the content and quality section are included in the moderate category. In the part of content that has not fulfilled, namely training for staff when there is a change in the content / format of the clinical pathway and the absence of training for new staff involved. For the quality section that has not fulfilled, the clinical pathway contents and documentation are routinely reviewed, evidence that the input from the patient has changed the practice and the involvement of patients in the contents of the clinical pathway. This is supported by the statement of the respondent 5 , that

"The socialization is new, if the one who makes the special seminar will be planned next year, the end of 2017. The seminar will be especially new next year, if only now there are only a few new representatives to socialize the CP problem, from the WA group as well . The socialization was through the structural WA group, because in the end the CP filled the majority, instead it was the nurse, because the specialist was not very good."

Based on the statement stated that there was no socialization or training / training for the use of clinical pathways.

Based on interviews with respondents it was known that clinical pathway was formed in 2014 by a clinical pathway team consisting of doctors, nurses, nutrition, pharmacy, laboratories. The making of clinical pathways based on the cases that most often found in Bantul X Hospital, cases with the highest costs and cases with the most variations. Clinical pathways are evaluated every 3 to 6 months by the clinical pathway team.

Clinical pathway is a new form in Bantul X hospital so it is difficult to change the habits in the field that previously did not use clinical pathway forms. The factor of noncompliance in the implementation of clinical pathway was still lacking due to the busyness of each officer so that they did not have time to fill the clinical pathway. Another thing that also caused non-compliance was that they were not familiar with the clinical pathway so they forgot to enter the medical record and the difference between the initial and final diagnosis.

f. Output 


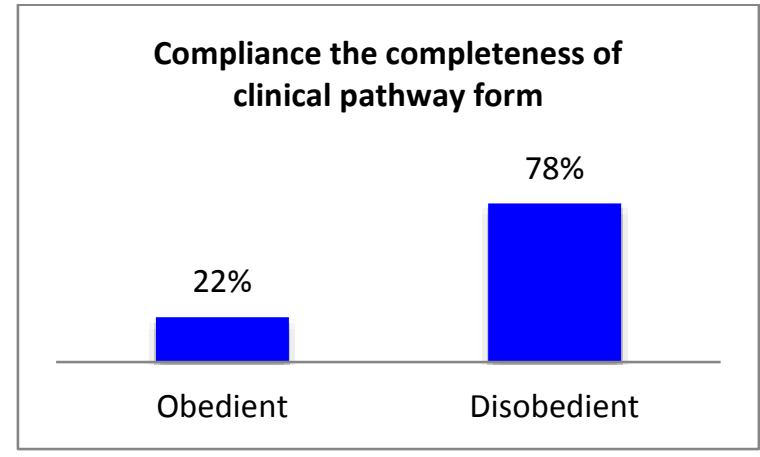

Based on medical record observation result, it is known that in term of the compliance of clinical pathway, there were only 6 of 27 medical records that attached the clinical pathway form. This result is supported by respondent 3 who stated,

"It is not usually filled in the emergency department so that we are not accustomed to filling CP."

Based on this statement it is known that the clinical pathway sheet is not always attached to the patient's medical record.

\begin{tabular}{|c|}
\hline $\begin{array}{c}\text { Completeness of the clinical pathway } \\
\text { contents }\end{array}$ \\
$0 \%$ \\
\hline Complete \\
\hline
\end{tabular}

Based on the result of the observation of medical record on the content of clinical pathway, the completeness level of contents of clinical pathway was $0 \%$. Based on the observation result, none of clinical pathway is filled completely. Furthermore, the researchers confirmed the results of observations related to data that does not exist to the interviewed respondents. Respondent 4 stated that

"Yes, sometimes it is filled and sometimes it is not. In such cases, it is filled when MR is going home."

Based on the statement it is known that the data that is not filled in the actual implementation is done, but forgot to fill in the medical record sheet.

\section{DISCUSSION}

a. Input

In $1^{\text {st }}$ dimension on the ICPAT (Integrated Clinical Pathways Apprasial Tools) assessment sheet, which is the form considered to be true clinical pathway. Content and quality are in good category. In this $1^{\text {st }}$ dimension, it is ensured that those assessed are clinical pathways. Because there is a lot of confusion over the definition of clinical pathway. ${ }^{12}$ The first step that needs to be done is to assess whether a guideline to be assessed is a clinical pathway or not. Because there is no one definition of clinical pathway, the list of questions in dimension 1 is obtained from a summary of various definitions that are well known, especially in the UK. ${ }^{13}$ A clinical pathway form was used to create a framework in the treatment process. So that a good clinical pathway format needs to be made to improve patient safety and the effectiveness of medical services. ${ }^{14}$ Clinical pathways are tools that are used as evidence-based health care guidelines. ${ }^{15}$ One way to improve quality is to redesign the health care process in the form of clinical pathways. ${ }^{16}$

From the ICPAT (Integrated Clinical Pathways Apprasial Tools) assessment, dimension 6, the content and quality section is included in the good category. Dimension 6 is an assessment of the role of the organization for the clinical pathway. From the results of research that has been carried out shows that hospitals have formed clinical pathway teams that have been socialized through various meetings and delivery to medical servants on inpatient wards. The main role of the organization is to form strong commitment and clinical leadership, one of them is a doctor. ${ }^{17}$ The lack of physician involvement is one reason for the failure of clinical pathway implementation. ${ }^{18}$

The Regulation of the Minister of Health of the Republic of Indonesia No. 56 of 2014 for the type C hospitals mentions that medical staffs shall include 9 general practitioners, 2 general dentists, 2 basic specialists, 1 supporting specialist and 1 dental and oral specialist. The medical staffs at Bantul X Hospital have met the standards. It has a neurologist and there is a doctor who helps the medical services to be maximal.

\section{b. Process}

From ICPAT (Integrated Clinical Pathways Apprasial Tools) dimension 3, the content section is included in the moderated category and the quality section is in the good category. Dimension 3 is an assessment of the clinical pathway development process. The process of developing clinical pathways is as important as the clinical pathways 
produced, because clinical pathways are tools that will also be used to evaluate services or therapies that have been given and to improve these services must involve a process of change in daily practice. ${ }^{13}$ One of the process of developing clinical pathway is the mapping process, with the mapping process producing a map of the patient's journey based on various perspectives. From the map the multidisciplinary team can examine the problem and the steps that will be used. The mapping process is the most important stage. ${ }^{19}$ One aspect that influences the preset results from dimension 3 is the absence of patient involvement in the development of clinical pathways. Patient involvement is very important in the development of a clinical pathway, one of the important things to note in the development of a clinical pathway is transparency of patients. ${ }^{20}$ Lack of accountability in the quality and transparency service process in patients can affect the process of developing clinical pathways. ${ }^{21}$

From the ICPAT (Integrated Clinical Pathways Apprasial Tools) dimension 4, the content and quality section is in the poor category. Dimension 4 is an assessment of the process of implementing clinical pathways. Implementation is very important because a manufacturing pathway is based on high risk, high volume, and high cost so that it is expected that the implementation of good clinical pathways can reduce the risk, amount, and cost of medical services. ${ }^{22}$ Clinical pathways can reduce the cost of treatment, this is evidenced by research that there is a difference between cost of treaties based on clinical pathway compared to the cost of treatment based on real conditions. ${ }^{23}$ Clinical pathways improve the quality of services and control the cost of care, the implementation of good clinical pathways can improve patient safety, satisfaction, and outcomes. ${ }^{24}$ Based on the Standard Operating Procedures for filling in clinical pathways in Bantul X hospital, the clinical pathway filling procedure starts from the Emergency Room or outpatient services filled by doctors and nurses. This is done if the disease case has been diagnosed from the initial service, but there is no procedure that states that filling in clinical pathways can be started on inpatient wards if there are cases of disease based on existing clinical pathways. This can make a lack of compliance with clinical pathway when clinical pathway is filled only from the emergency room and outpatient services.

From the ICPAT (Integrated Clinical Pathways Apprasial Tools) dimension 5, the content section is included in the moderate category and the quality section is included in the moderate category. Dimension 5 is an assessment of the maintenance of clinical pathways. One of the most important success factors in the use of clinical pathways is the maintenance of clinical pathways which requires that clinical pathways function as dynamic tools that can respond to input from staff, patients, clinical responses, recent references so that the contents and design of the clinical pathway need to be reviewed continuously. ${ }^{13}$ The success of clinical pathway maintenance depends on clinical service providers and managers, relevant staff involvement is needed to ensure goals are achieved at each stage of maintenance. ${ }^{25}$

From the ICPAT (Integrated Clinical Pathways Apprasial Tools) assessment, dimension 6, the content and quality section is included in the good category. Dimension 6 is an assessment of the role of the organization for the clinical pathway. From the results of research that has been carried out shows that hospitals have formed clinical pathway teams that have been socialized through various meetings and delivery to medical servants on inpatient wards. The main role of the organization is to form strong commitment and clinical leadership, one of which is a doctor. ${ }^{17}$ The lack of physician involvement is one reason for the failure of clinical pathway implementation. ${ }^{20}$

\section{c. Output}

Based on observations on medical records for the level of compliance with compliance and compliance with completeness of clinical pathway forms. There were only 6 medical records from 27 observed medical records that attached clinical pathway forms. From the percentage results it was concluded that $78 \%$ did not comply with the completeness of the clinical pathway form. Researchers also observed the contents of the clinical pathway. The level of completeness of the contents of the $0 \%$ clinical pathway was obtained, which from the observations of none of the clinical pathways that were filled in completely. Compliance in the implementation of clinical pathways can also improve communication between medical personnel. ${ }^{26}$

Based on interviews with respondents it was known that clinical pathway was formed in 2014 by a clinical pathway team consisting of doctors, nurses, nutrition, pharmacy, laboratories. Clinical pathway is a new form in Bantul X hospital so it is difficult to change habits in the field that previously did not use clinical pathway forms. The factor of non-compliance in the implementation of clinical pathway was still lacking due to the busyness of each officer so that they did not have time to fill the clinical pathway. Another thing that also caused non-compliance was that they were not familiar with the clinical pathway so 
they forgot to enter the medical record and there were differences in initial diagnosis and final diagnosis.

From the quality section also added constraints in the compliance of clinical pathway implementation that is because the evaluation process and results were not optimal. This is because the evaluation process itself is a little difficult because each member of the clinical pathway team also has another main task.

\section{d. Problems and recommendation}

The compliance factor in the implementation of clinical pathway is still lacking that is caused by busyness of each staff. They did not have time to fill the clinical pathway form. Another point that also causes the noncompliance is that they are not familiar with the clinical pathway yet so that they tend to forget to include in the medical record as well as the difference between the early diagnosis and final diagnosis.

The absence of awareness among medical personnel to remind each other about the clinical pathway sheet is to enter the clinical pathway into the medical record and fill the clinical pathway, it makes the importance of full time facilitators to oversee the implementation of clinical pathways. The medical personnel involved should know the importance of clinical pathways for quality control and cost control. So, training for staff involved in the implementation of medical personnel.

\section{CONCLUSION}

Based on the input aspect, the clinical pathway infarct cerebral form is considered to be a clinical pathway and has met the good category, the hospital has shown the role that meet the good category, the number of human resources for the specialist doctors as standard, while for the nursing staff, especially the ward B still not meet the standards, as well as there are some nursing equipment that is still less in number and also damaged.

Based on the process aspect, the documentation of the clinical pathway in the ward has been incorporated into the medical record with compliance rate of only $22 \%$ due to unaccustomed, lack of awareness, limited time, and forgetting, the development of clinical pathway has involved clinical pathway team, medical committee, nurse, pharmacy and other professions, but not optimal, the implementation process of clinical pathway is still hampered because there is still no training or special training related to clinical pathway. And for the output aspect , compliance complements the content of the clinical pathway by $0 \%$. To improve the quality of clinical pathway implementation, every medical and non-medical personnel involved should be reminded of each other, need for training for the staff involved, and a full time facilitator to supervise the implementation of clinical pathway. Suggestion are To improve the process of documenting clinical pathways, it is better for medical personnel to remind each other of clinical pathway forms. In an effort to maintain the use of clinical pathways, the hospital should conduct special training or training for staff involved in clinical pathways. In the effort to develop clinical pathways it is best to conduct regular reviews by the clinical pathway team by involving medical staff related to the clinical pathway.

In an effort to improve the function of clinical pathways as quality control and cost control it is expected to add clinical pathways with various variations that are often found in Bantul X Hospital. In an effort to improve the process of implementing and adhering to the filling of clinical pathways, it is best to involve roles that have enough power or top management to control the process of filling in and evaluating clinical pathways and socialization to all staff involved in the clinical pathway implementation process. A facilitator or coordinator is held who has full-time duties to ensure that clinical pathways can be applied optimally at Bantul X Hospital. Improvement of Standard Operating Procedures for filling in clinical pathways, namely filling in clinical pathways not only starting from the emergency department or outpatient care but starting from the time the patient is diagnosed and treatment is started. Add medical personnel who do not meet the standards

\section{REFERENCE}

1. Hatta, G. . (2010). Pedoman Manajemen Informasi Kesehatan di Sarana Pelayanan Kesehatan. Jakarta: UI Press.

2. Djasri, O. H. (2013). Peran Clinical Pathways dalam Sistem Jaminan Sosial Nasional Bidang Kesehatan 1, 3-7.

3. Donnan, G. A., Fisher, M., Macleod, M., \& Davis, S. M. (2008). Stroke. Lancet. https://doi.org/10.1016/S0140-6736(08)60694-7

4. Badan Penelitian dan Pengembangan Kesehatan. (2013). Riset Kesehatan Dasar (RISKESDAS) 2013. Laporan Nasional 2013, 1-384. https://doi.org/1 Desember 2013

5. Whittle, C. (2009). ICPAT: Integrated care pathways appraisal tool. International Journal of Care Pathways. 
https://doi.org/10.1258/jicp.2009.009012

6. Cheah, J. (2000). Clinical Pathways - An Evaluation of its Impact on the Quality of Care in an Acute Care General Hospital in Singapore, 41(7), 335-346.

7. Firmanda, D. (2006). Clinical Pathways Kesehatan Anak, 8(3), 195-208.

8. Rivany, R. (2009). Indonesia Diagnosis Related Groups. Kesmas: National Public Health Journal, 4(1), 3. https://doi.org/10.21109/kesmas.v4i1.194

9. Middleton, S.,Roberts, A., 2000, Integrated Care Pathways; A Practical Approach to Implementation, Butterworth-Heinemann:Reed Educational and Professional Publishing.

10. Vanhaecht, K., De Witte, K., Depreitere, R., \& Sermeus, W. (2006). Clinical pathway audit tools: A systematic review. Journal of Nursing Management. https://doi.org/10.1111/j.1365-2934.2006.00705.x

11. Croucher, M. (2005). An Evaluation of The Quality of Integrated Care Pathway Development in the UK National Health Service. Journal of Integrated Care Pathways, 9, 6-12.

12. De Luc, K. (2000). Care pathways: An evaluation of their effectiveness. Journal of Advanced Nursing. https://doi.org/10.1046/j.1365-2648.2000.01500.x

13. de Chernatony, L., \& Dall'Olmo Riley, F. (1998). Modelling the components of the brand. European Journal of Marketing. https://doi.org/10.1108/03090569810243721

14. Kinsman, L., Rotter, T., James, E., Snow, P., \& Willis, J. (2010). What is a clinical pathway? Development of a definition to inform the debate, 8-10.

15. Cui, Q., Tian, J., Song, X., Yang, K., \& Zhang, P. (2014). Effectiveness of Clinical Pathway in Breast Cancer Patients : A Meta-Analysis, 1-7.

16. Rejeki, V. M. M. (2014). Cost of Treatment Demam Berdarah Dengue ( DBD ) di Rawat Inap Berdasarkan Clinical Pathway di RS X Jakarta. Jurnal Ekonomi Kesehatan Indonesia, 2, 66-74.

17. Olsson, L. E., Hansson, E., Ekman, I., \& Karlsson, J, 2009, A cost-effectiveness study of a patient-centred integrated care pathway, Journal of Advanced Nursing. https://doi.org/10.1111/j.13652648.2009.05017.x

18. Devitra, A. (2011). Analisis Implementasi Clinical Pathway kasus Stroke berdasarkan INA-CBGs di Rumah Sakit Stroke Bukit Tinggi. Universitas Andalas.

19. Bjurling-sjöberg, P., \& Student, D. (2014). Preprint Prevalence and Quality of Clinical Pathways in Swedish Intensive Care Units : A National Survey, 20, $48-57$.

20. Healthcare, N. L. and I. A. for, \& Iechyd, A. G. A. ac A. dros O. (2005). Integrated Care Pathways. https://doi.org/10.1258/jicp.2009.009012

21. Chawla, A., Westrich, K., Matter, S., Kaltenboeck, A., \& Dubois, R. (2016). Care pathways in US healthcare settings: Current successes and limitations, and future challenges. American Journal of Managed Care, 22(1), 53-62.

22. Abrahams, E., Balch, A., Goldsmith, P., Kean, M., Miller, A. M., Omenn, G., ... Westrich, K. (2017). Clinical pathways: Recommendations for putting patients at the center of value-based care. Clinical Cancer Research, 23(16), 4545-4549. https://doi.org/10.1158/1078-0432.CCR-17-1609

23. Huang, D. (2015). Effects of clinical pathways in stroke management : A meta-analysis, 20(4), 335-342.

24. Aljunid, syed mohamed. (2012). Clinical Pathways : Development and Implementation at a Tertiary Hospital in Malaysia. International Journal of Public Health Research, 2(2), 153-160.

25. Evans-lacko, S., Jarrett, M., Mccrone, P., \& Thornicroft, G. (2010). Facilitators and barriers to implementing clinical care pathways.

26. Mater, W., Ibrahim, R., \& Ph, D. (2014). Delivering Quality Healthcare Services using Clinical Pathways, 95(1), 12-15. 